\title{
IMPLEMENTASI MODEL PEMBELAJARAN KOOPERATIF TIPE STUDENT TEAMS ACHIEVEMENT DIVISONS (STAD) UNTUK MENINGKATKAN MOTIVASI DAN HASIL BELAJAR AKUNTANSI SISWA KELAS XI IPS 1 SMA NURUL IMAN PALEMBANG TAHUN AJARAN 2015/2016
}

\author{
Oleh: Nuryanti Permata Sari \\ (UNIVERSITAS PGRI PALEMBANG)
}

nuryantips80@gmail.com

\begin{abstract}
Abstrak-Motivasi belajar siswa kelas XI IPS 1 SMA Nurul Iman Palembang masih rendah sehingga kemauan untuk belajar kurang sehingga hasil belajar rendah. Dengan menerapkan metode pembelajaran STAD siswa dituntut lebih aktif dalam pembelajaran sehingga dapat meningkatkan motivasi dan hasil belajar siswa, oleh sebab itu peneliti tertarik mengadakan penelitian tindakan kelas dengan tujuan untuk meningkatkan motivasi dan hasil belajar siswa dengan menggunakan penerapan metode pembelajaran kooperatif tipe STAD. Penelitian ini merupakan Penelitian Tindakan Kelas (PTK) yang ditempuh dalam dua siklus. Subjek penelitian adalah siswa kelas XI IPS 1 SMA Nurul Iman Palembang yang berjumlah 32 siswa. Instrumen untuk mengetahui motivasi belajar siswa dan respon siswa berupa angket, untuk mengetahui aktivitas guru dan murid instrumen yang digunakan adalah lembar observasi. Hasil penelitian menunjukkan bahwa pembelajaran kooperatif tipe STAD dapat meningkatkan motivasi belajar siswa pada siklus I sebesar 67\%, siklus II sebesar 86,5\% dan hasil belajar siswa, yang pada setiap siklusnya meningkat sebesar 96,25\%. Selain itu aktivitas guru dalam mengelola pembelajaran telah sangat baik, sedangkan aktivitas siswa semakin baik. Dan hasil respon siswa terhadap pelaksanaan model pembelajaran kooperatif tipe STAD untuk meningkatkan motivasi dan hasil belajar siswa juga mendapat respon positif.
\end{abstract}

Kata kunci: Metode Pembelajaran, Kooperatif Tipe STAD, Motivasi, Hasil Belajar.

\begin{abstract}
The learning motivation of students of class XI IPS 1 in SMA Nurul Iman Palembang is still low so that the willingness to learn is lacking so that learning outcomes are low. By applying the STAD learning method students are required to be more active in learning so that they can increase motivation and student learning outcomes, therefore researchers are interested in conducting classroom action research with the aim of increasing student motivation and learning outcomes by using the STAD type cooperative learning method. This research is a Classroom Action Research (CAR) which was carried out in two cycles. The research subjects were students of class XI IPS 1 in SMA Nurul Iman Palembang, totaling 32 students. Instruments to determine student learning motivation and student responses in the form of questionnaires, to find out the activities of teachers and students the instruments used were observation sheets.
\end{abstract}


The results showed that STAD type cooperative learning could increase student motivation in the first cycle by $67 \%$, cycle II at $86.5 \%$ and student learning outcomes, which in each cycle increased by $96.25 \%$. In addition, the teacher's activities in managing learning have been very good, while student activities are getting better. And the results of student responses to the implementation of the STAD type cooperative learning model to increase student motivation and learning outcomes also received a positive response.

Keywords: STAD type cooperative learning method, motivation and learning outcomes.

\section{Pendahuluan}

Pendidikan

merupakan

pondasi pokok dalam kelangsungan hidup suatu bangsa. Pendidikan dapat dijadikan sebagai alat ukur keberhasilan suatu bangsa dalam hal pemeliharaan dan perbaikan kehidupan masyarakat. Hal ini karena pendidikan memegang peranan penting untuk meningkatkan dan mengembangkan Sumber Daya Manusia (SDM). Sistem pendidikan yang baik pada suatu negara akan mampu menghasilkan SDM yang berkualitas, dapat diandalkan, kompeten, dan profesional dalam bidangnya, serta memiliki kemandirian sebagai modal untuk bersaing dengan dunia luar. Dalam perkembangannya, istilah pendidikan atau pedagogie berarti bimbingan atau pertolongan yang diberikan dengan sengaja oleh orang dewasa agar ia menjadi dewasa. Selanjutnya, berdasarkan Sudirman, dkk. (1992: 4), pendidikan diartikan sebagai usaha yang dijalankan oleh seseorang atau kelompok orang lain agar menjadi dewasa atau mencapai tingkat hidup atau penghidupan yang lebih tinggi dalam arti mental.

\section{Undang-undang}

Sistem

Pendidikan Nasional (UUSPN) Nomor 20 Tahun 2003 pasal 1 ayat (1) (Hasbullah, 2005: menyebutkan bahwa Pendidikan adalah usaha sadar dan terencana untuk mewujudkan suasana belajar dalam proses pembelajaran agar peserta didik secara aktif mengembangkan potensi dirinya untuk memiliki kekuatan spiritual keagamaan, pengendalian diri, kecerdasan, akhlak mulia, serta keterampilan yang diperlukan dirinya, masyarakat, bangsa, dan negara. Oleh karena itu peningkatan mutu pendidikan harus diikuti peningkatan mutu peserta didik yang menjadi subjek didik.

Dewasa ini, sistem pembelajaran berbasis peserta didik telah dikembangkan, hal tersebut telah tercantum pada Undang-undang Sistem Pendidikan Nasional (UUSPN) Nomor 20 Tahun 2003 pasal 3 yaitu: Pendidikan nasional berfungsi mengembangkan kemampuan dan membentuk watak serta peradaban bangsa yang bermartabat dalam rangka mencerdaskan kehidupan bangsa, 
bertujuan untuk berkembangnya potensi peserta didik agar menjadi manusia yang beriman dan bertakwa kepada Tuhan Yang Maha Esa, berakhlak mulia, sehat, berilmu, cakap, kreatif, mandiri, dan menjadi warga negara yang demokratis serta bertanggungjawab.

Guru diharapkan mampu mengembangkan inovasi dan kreativitas dalam rangka mewujudkan tujuan pembelajaran yang sesuai dengan tujuan pendidikan nasional. Namun, tidak dapat dipungkiri bahwa masih banyak hambatan bagi guru untuk menerapkan sistem pendidikan berbasis peserta didik. Hambatan yang umumnya ditemui oleh para guru adalah melakukan variasi ketika kegiatan pembelajaran berlangsung. Guru cenderung melaksanakan kegiatan pembelajaran dengan model pembelajaran konvensional yang menjadikan peserta didik sebagai objek, yaitu peserta didik lebih banyak mencatat, dan mendengarkan ceramah materi dari guru, tanpa diimbangi variasi model pembelajaran yang menarik bagi peserta didik. Adanya hambatan semacam ini yang mengakibatkan peserta didik kurang aktif berpartisipasi dalam proses belajar mengajar, peserta didik tidak dapat fokus pada materi yang diajarkan dan rasa bosan untuk belajar semakin meningkat, sehingga motivasi dan hasil belajar peserta didik pun kurang baik.
Penerapan

model

pembelajaran di SMA Nurul Iman Palembang pada mata pelajaran Akuntansi kelas XI IPS 1 masih belum cukup bervariasi, model pembelajaran yang masih diterapkan adalah model pembelajaran konvensional yaitu ceramah. Model pembelajaran seperti ini bersifat satu arah sehingga siswa kurang aktif dalam kegiatan pembelajaran di kelas. Pada pelaksanaan kegiatan pembelajaran, guru menjelaskan materi dengan metode ceramah, sedangkan siswa mencatat penjelasan guru. Berdasarkan hasil observasi, di antara 32 siswa tidak lebih dari $60 \%$ siswa yang memperhatikan penjelasan guru, siswa lain lebih banyak menggunakan kesempatan tersebut untuk bermain dengan temannya atau melakukan aktivitas lain yang tidak berkaitan dengan materi yang sedang diajarkan guru. Hal yang sama terjadi ketika guru memberi kesempatan untuk membaca buku-buku referensi dari perpustakaan, siswa terlihat malas membaca dan lebih banyak bermain. Padahal apabila siswa ingin memahami materi dengan baik, mereka juga harus membaca materi dari buku referensi dan tidak hanya menjadikan guru sebagai sumber ilmu.

Berdasarkan ilustrasi tersebut menunjukkan bahwa siswa bosan dan kurang termotivasi untuk mengikuti pelajaran. Pemahaman siswa terhadap suatu materi pun sangat 
kurang, terbukti pada saat guru memberikan tugas, siswa tidak segera mengerjakan melainkan sibuk saling bertanya kepada teman dan teman yang ditanya pun kadang memiliki kompetensi yang kurang dalam memberikan jawaban, tidak jarang siswa mengeluh tentang sulitnya mencari jawaban dari tugas tersebut. Hasil belajar Akuntansi siswa kelas XI IPS 1 juga belum menunjukkan hasil belajar yang optimal, sebanyak $60 \%$ siswa belum berhasil mencapai Kriteria Ketuntasan Minimal (KKM).

Kenyataan tersebut

menunjukkan adanya suatu masalah dalam pembelajaran Akuntansi kelas XI IPS 1 SMA Nurul Iman Palembang, siswa kurang memiliki motivasi untuk belajar dan memahami materi akuntansi dengan baik sehingga hasil belajar akuntansi cenderung rendah. Guna menyelesaikan permasalahan model pembelajaran yang bersifat konvensional, pemahaman siswa yang masih kurang, motivasi dan hasil belajar siswa yang masih rendah, maka diperlukan suatu model pembelajaran yang lebih efektif dan lebih menekankan pada keaktifan belajar siswa pada kegiatan pembelajaran.

Salah satu alternatif yang dapat diterapkan adalah melalui penerapan model pembelajaran kooperatif. Pembelajaran dengan model kooperatif merupakan model pembelajaran dengan cara mengelompokkan siswa berdasarkan tingkat kemampuan yang berbedabeda dalam kelompok kecil untuk bekerjasama mencapai tujuan belajar. Model pembelajaran kooperatif menuntut kerjasama dan interdependensi siswa dalam struktur tugas, struktur tujuan, dan struktur reward-nya. Terdapat beberapa macam pendekatan model pembelajaran kooperatif yang dapat diterapkan guru dalam proses belajar mengajar di kelas. Trianto (2010: 67) menyebutkan pendekatan model pembelajaran kooperatif meliputi: Student Teams Achievement Divisions (STAD), Jigsaw, Investigasi Kelompok (Teams Games Tournaments atau TGT), dan pendekatan Struktural.

Dari beberapa tipe pembelajaran kooperatif tersebut, tipe pembelajaran Student Teams Achievement Divisions (STAD) merupakan tipe pembelajaran kooperatif yang lebih sederhana diterapkan di kelas dan lebih mudah pula diterapkan oleh pemula. Model pembelajaran STAD menempatkan pada partisipasi aktif siswa dalam kelompok belajar. Pada pembelajaran ini, siswa dibagi menjadi beberapa kelompok atau tim, masing-masing terdiri atas 4 atau 5 anggota kelompok. Tiap tim memiliki anggota yang bersifat heterogen, baik jenis kelamin, ras, etnik, maupun kemampuannya (tinggi, sedang dan rendah), masing-masing siswa dapat bertukar pikiran, siswa yang 
memiliki kemampuan lebih tinggi dapat membantu siswa yang memiliki kemampuan lebih rendah. Siswa saling bekerjasama untuk memahami materi belajar dan menyelesaikan tugas kelompok.

Berdasarkan latar belakang tersebut, dapat diidentifikasi permasalahan-permasalahan berikut:

1. Aktivitas belajar mengajar masih menjadikan guru sebagai center of learning dan belum menerapkan sistem pembelajaran berbasis peserta didik.

2. Kurangnya variasi guru dalam menggunakan model pembelajaran yang lebih inovatif pada kegiatan belajar mengajar Akuntansi di kelas.

3. Guru lebih banyak menerapkan model pembelajaran konvensional berupa ceramah yang bersifat satu arah sehingga siswa kurang aktif dalam kegiatan pembelajaran.

4. Kurangnya motivasi belajar siswa pada mata pelajaran Akuntansi karena pembelajaran di dalam kelas belum dirancang untuk meningkatkan motivasi belajar siswa.

5. Adanya kecenderungan hasil belajar siswa pada mata pelajaran Akuntansi masih rendah yaitu sebanyak $60 \%$ siswa belum mampu mencapai KKM.

Berdasarkan masalah yang diuraikan di atas maka rumusan permasalahan dalam penelitian ini adalah:

1. Bagaimanakah Peningkatan Hasil Belajar Akuntansi Siswa melalui Implementasi Model Pembelajaran Kooperatif Tipe Student Teams Achievement Divisons (STAD) pada Siswa Kelas XI IPS 1 SMA Nurul Iman Palembang Tahun Ajaran 2015/2016?

2. Bagaimanakah Peningkatan Motivasi Belajar Akuntansi Siswa melalui Implementasi Model Pembelajaran Kooperatif Tipe Student Teams Achievement Divisons (STAD) pada Siswa Kelas XI IPS 1 SMA Nurul Iman Palembang Tahun Ajaran 2015/2016?

3. Bagaimanakah Respon Siswa dalam Implementasi Model Pembelajaran Kooperatif Tipe Student Teams Achievement Divisons (STAD) untuk Meningkatkan Motivasi dan Hasil Belajar Siswa Kelas XI IPS 1 SMA Nurul Iman Palembang Tahun Ajaran 2015/2016?

\section{Kajian Teoritis}

1. Tinjauan Mengenai Hasil Belajar Akuntansi

a. Pengertian Belajar Menurut Hilgrad dan Bower (1975) dikutip oleh Fudyartanto (2002: 15) belajar (to learn) memiliki arti: 1) to gain knowledge, comprehension, or mastery of trough 
experience or study; 2) to fix in the main or memory; memorize; 3) to acquire trough experience; 4) to become in form of to find out. Menurut definisi tersebut, belajar memiliki pengertian memperoleh pengetahuan atau menguasai pengetahuan melalui pengalaman, mengingat, menguasai pengalaman, dan mendapatkan informasi atau menemukan, dengan demikian, belajar memiliki arti dasar adanya aktivitas atau kegiatan dan penguasaan tentang sesuatu.

\section{b. Ciri-ciri Belajar}

Dari definisi para ahli dapat ditemukan mengenai ciri-ciri belajar (Baharuddin dan Esa Nur Wahyuni, 2009: 15) yaitu:

1) Belajar ditandai dengan adanya perubahan tingkah laku (change behaviour).

2) Perubahan perilaku relatif permanen.

3) Perubahan tingkah laku tidak harus segera dapat diamati pada saat proses belajar sedang berlangsung, perubahan perilaku tersebut bersifat potensial.

4) Perubahan tingkah laku merupakan hasil latihan atau pengalaman.

5) Pengalaman atau latihan tersebut dapat memberi penguatan.

Berdasarkan

Teori

Taksonomi Benjamin S. Bloom (Abdurrahman, 2003: 38), ada tiga ranah (domain) hasil belajar yaitu kognitif, afektif dan psikomotorik.
Hasil belajar kognitif yaitu, hasil belajar yang berdasarkan pengalaman, sedangkan hasil belajar yang afektif yaitu dengan cara mengenal dengan cara merasakan, dan hasil belajar psikomotorik yaitu hasil belajar berdasarkan sikap atau aktivitas anak didik tersebut. Sehingga dapat disimpulkan bahwa hasil belajar merupakan pencapaian bentuk perubahan perilaku yang cenderung menetap dari ranah kognitif, afektif, dan psikomotorik dari proses belajar yang dilakukan dalam waktu tertentu.

c. Indikator Hasil Belajar

Menurut Sudjana (Asep Jihad dan Abdul Haris, 2008: 2), terdapat dua kriteria hasil belajar yang meliputi:

1) Kriteria ditinjau dari sudut prosesnya

a) Apakah pengajaran direncanakan dan dipersiapkan terlebih dahulu oleh guru dengan melibatkan siswa secara sistematik?

b) Apakah kegiatan siswa belajar dimotivasi guru sehingga ia melakukan kegiatan belajar dengan penuh kesabaran, kesungguhan dan tanpa paksaan untuk memperoleh tingkat penguasaan, pengetahuan, kemampuan serta sikap yang dikehendaki dari pengajaran itu?

c) Apakah guru memakai multimedia? 
d) Apakah siswa mempunyai kesempatan untuk mengontrol dan menilai sendiri hasil belajar yang dicapainya?

e) Apakah proses pengajaran dapat melibatkan semua siswa dalam kelas?

f) Apakah suasana pengajaran atau proses belajar mengajar cukup menyenangkan dan merangsang siswa belajar?

g) Apakah kelas memiliki sarana belajar yang cukup kaya, sehingga menjadi laboratorium belajar?

2) Kriteria ditinjau dari hasilnya

a) Apakah hasil belajar yang diperoleh siswa dari proses pengajaran nampak dalam bentuk perubahan tingkah laku secara menyeluruh?

b) Apakah hasil belajar yang dicapai siswa dari proses pengajaran dapat diaplikasikan dalam kehidupan siswa?

c) Apakah hasil belajar yang diperoleh siswa tahan lama diingat dan mengendap dalam pikirannya, serta cukup mempengaruhi perilaku dirinya?

d) Apakah yakin bahwa perubahan yang ditunjukkan oleh siswa merupakan akibat dari proses pengajaran?

2. Tinjauan Mengenai Motivasi Belajar Akuntansi

a. Pengertian Motivasi Belajar

Menurut Sardiman (2007: 73), "motif diartikan sebagai daya upaya yang mendorong seseorang untuk melakukan aktivitas-aktivitas tertentu demi mencapai suatu tujuan". Berawal dari kata motif maka motivasi dapat diartikan sebagai daya penggerak yang telah menjadi aktif. Motif menjadi aktif pada saat-saat tertentu, terutama bila kebutuhan untuk mencapai tujuan sangat dirasakan atau mendesak. Selanjutnya berdasarkan Mc Donald (Sardiman, 2007: 73), "motivasi adalah perubahan energi dalam diri seseorang yang ditandai dengan munculnya feeling dan didahului dengan tanggapan terhadap adanya tujuan".

\section{b. Cara Meningkatkan Motivasi Belajar}

Guna menumbuhkan motivasi dalam kegiatan belajar di sekolah, terdapat beberapa bentuk dan cara yang disebutkan oleh Sardiman (2007: 92) antara lain: memberi angka, hadiah, saingan/kompetisi, ego-involvement, memberi ulangan, mengetahui hasil, pujian, hukuman, hasrat untuk belajar, minat, tujuan yang diakui.

c. Faktor - faktor Motivasi Belajar

1) Faktor internal adalah faktor yang ada dalam diri manusia itu sendiri yang berupa sikap, kepribadian, pendidikan, pengalaman dan cita-cita.

2) Faktor eksternal adalah faktor yang berasal dari luar diri manusia itu sendiri yang terdiri 
dari lingkungan sosial dan lingkungan non sosial (Muhibbin Syah, 2002).

\section{d. Prinsip-prinsip Motivasi Belajar} Keller (Sugihartono dkk, 2007: 78) menyusun seperangkat prinsip-prinsip motivasi yang dapat diterapkan pada proses belajar mengajar yang disebut sebagai model ARCS. Dalam model tersebut ada 4 kategori kondisi motivasional yang harus diperhatikan guru agar proses pembelajaran yang dilakukannya menarik, bermakna, dan memberi tantangan pada siswa. Keempat kondisi tersebut adalah: Attention (perhatian), Relevance (relevansi), Confidence (kepercayaan diri) dan Satisfaction (kepuasan).

\section{e. Unsur-unsur Motivasi Belajar Menurut Dimyati dan} Mudjiono (2003: 97) unsur-unsur yang mempengaruhi motivasi belajar adalah: cita-cita atau aspirasi siswa, kemampuan siswa, kondisi siswa, kondisi lingkungan siswa, unsurunsur dinamis dalam belajar dan pembelajaran, upaya guru dalam membelajarkan siswa.

3. Tinjauan Mengenai Model Pembelajaran Koperatif Tipe Student Teams Achievement Divisions (STAD)

a. Pengertian Pembelajaran Kooperatif

Pembelajaran kooperatif adalah model pembelajaran yang dirancang untuk membelajarkan kecakapan akademik (academic skill), sekaligus keterampilan social (social skill) termasuk interpersonal skill (Yatim Riyanto, 2008: 271). Arends (2008), mengemukakan model pengajaran pembelajaran kooperatif (cooperative learning), berupaya membantu siswa untuk mempelajari isi akademis dan berbagai keterampilan untuk mencapai berbagai sasaran dan tujuan sosial dan hubungan antarmanusia yang penting. Kunci dari pembelajaran kooperatif adalah bekerjasama. Kerjasama adalah suatu bentuk interaksi, merancang untuk memudahkan pencapaian tujuan lewat bekerjasama dalam kelompok.

\section{b. Unsur dan Ciri Pembelajaran Kooperatif \\ Menurut Lundgren} (Sukarmin, 2002: 2), unsur-unsur dasar yang perlu ditanamkan pada diri siswa agar cooperative learning lebih efektif adalah sebagai berikut :

1) Para siswa harus memiliki persepsi bahwa mereka "tenggelam atau berenang bersama".

2) Para siswa memiliki tanggung jawab terhadap tiap siswa lain dalam kelompoknya, di samping tanggung jawab terhadap diri sendiri, dalam mempelajari materi yang dihadapi.

3) Para siswa harus berpandangan bahwa mereka semuanya memiliki tujuan yang sama. 
4) Para siswa harus membagi tugas dan berbagi tanggung jawab sama besarnya di antara anggota kelompok.

5) Para siswa akan diberikan suatu evaluasi atau penghargaan yang akan ikut berpengaruh terhadap evaluasi seluruh anggota kelompok.

6) Para siswa berbagi kepemimpinan, sementara mereka memperoleh keterampilan bekerja sama selama belajar.

7) Para siswa akan diminta mempertanggungjawabkan secara individual materi yang ditangani dalam kelompok kooperatif.

\section{c. Pembelajaran Kooperatif Tipe} STAD

STAD dikembangkan oleh Slavin dan rekan-rekan sejawatnya di Hopkins University. Pendekatan ini merupakan pendekatan yang paling sederhana dan paling mudah dipahami. Guru yang menggunakan STAD menyajikan informasi akademis baru kepada siswa setiap minggu atau secara reguler, baik melalui presentasi verbal atau teks. Siswa di kelas tertentu dibagi menjadi beberapa kelompok atau tim belajar dari kedua gender (laki-laki dan perempuan), dari berbagai rasial atau etnis dan dengan prestasi rendah, rata-rata, dan tinggi. Anggota tim menggunakan worksheets atau alat belajar lain untuk menguasai berbagai materi akademis dan kemudian saling membantu untuk mempelajari berbagai materi melalui tutoring, saling memberikan kuis, atau melaksanakan diskusi tim. Secara individual, siswa diberi kuis mingguan atau dua minggu tentang berbagai materi akademis. Kuis-kuis diskor dan masing-masing individu diberi skor kemajuan untuk mengetahui perkembangan siswa.

Terdapat lima komponen utama dalam pembelajaran STAD antara lain sebagai berikut (dalam Mohamad Nur, 2005:20): presentasi kelas, kerja tim, kuis, skor perbaikan individual, penghargaan tim.

Berikut ini langkah-langkah pembelajaran kooperatif tipe STAD:

1) Kelompokkan siswa dengan masing-masing kelompok terdiri dari tiga sampai dengan lima orang. Anggota-anggota kelompok dibuat heterogen meliputi karakteristik kecerdasan, kemampuan awal bahasa Indonesia, motivasi belajar, jenis kelamin, ataupun latar belakang etnis yang berbeda.

2) Kegiatan pembelajaran dimulai dengan presentasi guru dalam menjelaskan pelajaran berupa paparan masalah, pemberian data, pemberian contoh. Tujuan presentasi adalah untuk mengenalkan konsep dan mendorong rasa ingin tahu siswa. 
3) Pemahaman konsep dilakukan dengan cara siswa diberi tugastugas kelompok. Mereka boleh mengerjakan tugas-tugas tersebut secara serentak atau saling bergantian menanyakan kepada temannya yang lain atau mendiskusikan masalah dalam kelompok, atau apa saja untuk menguasai materi pelajaran tersebut. Para siswa tidak hanya dituntut untuk mengisi lembar jawaban tetapi juga untuk mempelajari konsepnya. Anggota kelompok diberitahu bahwa mereka dianggap belum selesai mempelajari materi sampai semua anggota kelompok memahami materi pelajaran tersebut.

4) Siswa diberi tes atau kuis individual dan teman sekelompoknya tidak boleh menolong satu sama lain. Tes individual ini bertujuan untuk mengetahui tingkat penguasaan siswa terhadap suatu konsep dengan cara siswa diberikan soal yang dapat diselesaikan dengan cara menerapkan konsep yang dimiliki sebelumnya.

5) Hasil tes kuis selanjutnya dibandingkan dengan rata-rata sebelumnya dan poin akan diberikan berdasarkan tingkat keberhasilan siswa mencapai atau melebihi kinerja sebelumnya. Poin ini selanjutnya dijumlahkan untuk membentuk skor kelompok.
6) Setelah itu memberikan penghargaan kepada kelompok yang terbaik presentasinya atau yang telah memenuhi kriteria tertentu. Penghargaan dapat berupa hadiah, pujian, tambahan nilai dan lain-lain.

\section{Metode Penelitian}

Jenis penelitian ini merupakan Penelitian Tindakan Kelas (PTK) atau Classroom Action Research (CAR) yang dilakukan secara kolaboratif sehingga peneliti tidak melakukan penelitian sendiri, namun berkolaborasi atau bekerjasama dengan guru Akuntansi dan partisipatif yaitu peneliti secara langsung terlibat dalam pelaksanaan penelitian langkah demi langkah.

Adapun model Penelitian Tindakan Kelas menggunakan model yang dikembangkan Kemmis dan Taggart. Pada penelitian ini, dibagi menjadi dua siklus yang dijabarkan sebagai berikut.

1. Siklus I
a. Tahap Perencanaan
b. Tahap Pelaksanaan Tindakan
c. Tahap Observasi I
d. Tahap Refleksi Siklus I

2. Siklus II

a. Tahap Revisi Perencanaan

b. Tahap Pelaksanaan Tindakan

c. Tahap Observasi II

d. Tahap Refleksi Siklus II

Teknik pengumpulan data yang dilakukan pada penelitian ini adalah observasi dan angket siswa. Teknik analisis data yang digunakan 
dalam penelitian ini dilakukan secara terus-menerus selama pengumpulan data berlangsung sampai akhir penelitian atau penarikan kesimpulan. Dalam penelitian ini dilakukan dua bentuk analisis data yaitu analisis kualitatif dan analisis kuantitatif. Analisis data kualitatif dilakukan dengan tiga tahap:

1. Reduksi data

2. Penyajian data

3. Menarik kesimpulan

Langkah berikutnya dalam proses analisis data kualitatif adalah melakukan penarikan kesimpulan untuk menjawab permasalahan. Analisis data kuantitatif berupa data hasil observasi dan data angket diperoleh dengan cara memberikan skor pada setiap aspek komponen yang diamati. Setiap aspek pengamatan memiliki indikator ketercapaian yang dibuat dengan rentang skor 4, 3, 2, 1. Rumus untuk menghitung persentase hasil observasi dan data angket penerapan pembelajaran kooperatif tipe STAD dan motivasi belajar siswa yaitu:

$$
\% \text { penerapan pembelajaran }=\frac{\text { Skor total yang diperoleh }}{\text { Skor maksimal }} \times 100 \%
$$

$$
\% \text { motivasi belajar } \quad=\frac{\text { Skor total yang diperoleh }}{\text { Skor maksimal }} \times 100 \%
$$

Indikator keberhasilan pada penelitian ini apabila siswa dalam satu kelas mengalami peningkatan motivasi dan hasil belajar setelah diterapkan model pembelajaran kooperatif tipe STAD. Komponen yang menjadi indikator keberhasilan pada hasil belajar siswa adalah apabila siswa secara individual mengalami peningkatan hasil belajar dari satu siklus ke siklus berikutnya dan sudah memenuhi Kriteria Ketuntasan Minimal (KKM) yaitu 76. Sedangkan yang menjadi indikator keberhasilan motivasi belajar siswa dan respon siswa terhadap pelaksanaan pembelajaran apabila skor motivasi belajar siswa dan respon pelaksanaan pembelajaran siswa mengalami peningkatan dari satu siklus ke siklus berikutnya dan mencapai kategori tinggi yaitu $65 \%-84 \%$.

\section{Hasil dan Pembahasan Siklus I}

a. Hasil Observasi

Pengamatan dilakukan bersamaan dengan pelaksanaan tindakan. Peneliti berperan sebagai pengamat (observer), pengamat turut membantu guru dalam mengkondisikan siswa dan membantu tercapainya kegiatan belajar mengajar yang efektif. Pengamatan terhadap motivasi belajar siswa dalam pembelajaran akuntansi dengan penerapan pembelajaran kooperatif tipe STAD, sebagai berikut: 
Tabel 1. Hasil Persentase Pengamatan Motivasi Belajar Siswa Siklus I

\begin{tabular}{|c|c|c|c|}
\hline \multirow{2}{*}{ No } & \multicolumn{2}{|c|}{ Aspek yang diamati } & \multicolumn{2}{c|}{ Jumlah Skor } \\
\cline { 3 - 4 } & & $\begin{array}{c}\text { Pertemuan } \\
\mathbf{1}\end{array}$ & $\begin{array}{c}\text { Pertemuan } \\
\mathbf{2}\end{array}$ \\
\hline a) & $\begin{array}{l}\text { Perhatian siswa dalam mengikuti kegiatan } \\
\text { pembelajaran }\end{array}$ & 77 & 79 \\
\hline b) & Motivasi siswa dalam diskusi kelompok & 81 & 91 \\
\hline c) & Motivasi dalam mengerjakan tugas kelompok & 79 & 84 \\
\hline d) & Motivasi dalam mengerjakan tugas individu & 78 & 81 \\
\hline e) & Motivasi untuk bekerjasama dalam kelompok & 87 & 92 \\
\hline f) & Motivasi dalam memperoleh penghargaan & 81 & 84 \\
\hline & Skor total yang diperoleh & 483 & 511 \\
\hline \multicolumn{2}{|c|}{ Skor maksimal } & 744 & 744 \\
\hline
\end{tabular}

Nilai persentase motivasi belajar

pada siklus I adalah sebagai berikut:

$\%$ motivasi belajar

$=\frac{\text { Skor total yang diperoleh }}{\text { Skor maksimal }} \times 100 \%$
$=\frac{(483+511) / 2}{744} \times 100 \%$
$=67 \%$

Berdasarkan tabel 1, dapat dinyatakan bahwa motivasi belajar siswa pada siklus I menunjukkan hasil yang cukup optimal, telah terjadi peningkatan rata-rata skor kelas sebesar 28 poin dari pertemuan pertama ke pertemuan kedua. Persentase skor motivasi belajar juga menunjukkan skor tinggi karena berada pada rentang skor $65 \% \leq X \leq$ $84 \%$ yang mana $X$ adalah \% motivasi belajar siswa sebesar 67\%. Skor tersebut diperoleh dari jumlah skor total yang diperoleh pada pertemuan pertama dan kedua yang selanjutnya dibagi dengan jumlah skor maksimal.

b. Hasil Tindakan

Hasil tindakan pada siklus I berupa perolehan nilai post-test pada akhir siklus I yang diperoleh oleh siswa secara individu setelah dilakukan tindakan berupa pembelajaran kooperatif dengan tipe STAD. Berdasarkan hasil post-test terdapat 5 siswa yang nilainya masih di bawah KKM, sedangkan sebanyak 27 siswa telah mencapai KKM. Hasil 
siklus I selengkapnya akan disajikan dalam pembahasan.

\section{c. Tahap Refleksi}

Pada pelaksanaan siklus I masih banyak kekurangan yang terjadi diantaranya adalah:

1) Pengelolaan waktu kurang optimal sehingga harus menambah jam belajar selama 8 menit.

2) Pada pertemuan pertama, ditemui 7 siswa yang kurang tertarik terhadap materi pelajaran.

3) Dalam satu kelompok hanya satu atau dua siswa saja yang aktif dalam mengikuti diskusi kelompok maupun mengerjakan tugas kelompok, siswa lainnya hanya bermain dan menyalin jawaban temannya.

4) Guru masih belum menjangkau seluruh kelompok untuk membimbing siswa dalam kerja kelompok.

Langkah selanjutnya untuk memperbaiki siklus I, peneliti mengadakan perbaikan sebagai berikut.
1) Pengelolaan waktu yang lebih efektif sebelum pelajaran dimulai.

2) Membuat suasana belajar yang lebih memotivasi siswa untuk memahami materi secara mendalam, berani mengemukakan pendapatnya.

3) Guru lebih memotivasi siswa untuk bekerjasama dengan baik dalam menyelesaikan tugas kelompok agar setiap anggota kelompok dapat memahami materi yang diajarkan.

4) Guru lebih aktif berkeliling kelas untuk membimbing setiap kelompok maupun individu yang mengalami kesulitan belajar.

\section{Siklus II}

a. Hasil Observasi

Kegiatan pengamatan pada siklus II hampir sama dengan siklus I. Pengamatan dilakukan untuk mengetahui peningkatan motivasi belajar siswa. Hasil pengamatan motivasi belajar siswa dapat dilihat pada tabel berikut:

Tabel 2. Hasil Persentase Pengamatan Motivasi Belajar Siswa Siklus II

\begin{tabular}{|c|l|c|c|}
\hline \multirow{2}{*}{ No } & \multicolumn{1}{|c|}{ Aspek yang diamati } & \multicolumn{2}{|c|}{ Jumlah Skor } \\
\cline { 3 - 4 } & \multicolumn{1}{|c|}{$\begin{array}{c}\text { Pertemuan } \\
\mathbf{1}\end{array}$} & $\begin{array}{c}\text { Pertemuan } \\
\mathbf{2}\end{array}$ \\
\hline a) & $\begin{array}{l}\text { Perhatian siswa dalam mengikuti kegiatan } \\
\text { pembelajaran }\end{array}$ & 100 & 110 \\
\hline b) & Motivasi siswa dalam diskusi kelompok & 105 & 107 \\
\hline c) & Motivasi dalam mengerjakan tugas kelompok & 113 & 117 \\
\hline d) & Motivasi dalam mengerjakan tugas individu & 104 & 107 \\
\hline e) & Motivasi untuk bekerjasama dalam kelompok & 98 & 103 \\
\hline f) & Motivasi dalam memperoleh penghargaan & 107 & 117 \\
\hline
\end{tabular}




\begin{tabular}{|c|c|c|}
\hline Skor total yang diperoleh & 626 & 661 \\
\hline Skor maksimal & 744 & 744 \\
\hline
\end{tabular}

Nilai persentase motivasi belajar pada siklus I adalah sebagai berikut:

$\%$ motivasi belajar

$$
\begin{gathered}
=\frac{\text { Skor total yang diperoleh }}{\text { Skor maksimal }} \times 100 \% \\
\frac{(626+661) / 2}{744} \times 100 \% \\
744
\end{gathered}
$$

Tabel 2 menunjukkan persentase motivasi belajar siswa mengalami peningkatan sebesar 35 poin dari jumlah skor total yang diperoleh 626 menjadi 661, sehingga dihasilkan persentase motivasi belajar sebesar $86,5 \%$. Rentang skor $85 \% \leq X \leq 100 \%$ dengan $X=86,5 \%$ sudah menunjukkan rentang skor maksimal dan berada pada rentang skor kategori sangat tinggi.

\section{b. Hasil Tindakan}

Hasil tindakan pada siklus II berupa perolehan nilai tes akhir siklus II yang telah diperoleh siswa. Melalui perbaikan-perbaikan yang dilakukan, maka hasil nilai tes akhir siswa mengalami peningkatan yang sangat signifikan, $100 \%$ siswa dari kelas XI IPS 1 telah memenuhi Kriteria Ketuntasan Minimal (KKM) dengan nilai rata-rata kelas sebesar 96,25\%. Penjelasan lebih lanjut mengenai hasil nilai tes akhir siswa akan dikaji pada pembahasan.

$$
86,5 \%
$$

c. Tahap Refleksi

Hasil penelitian pada siklus II secara keseluruhan menunjukkan peningkatan Hasil Belajar Akuntansi siswa melalui pembelajaran kooperatif tipe STAD. Berdasarkan Hasil Belajar Akuntansi siklus II telah mengalami peningkatan dari siklus I. Siswa sudah dapat mengikuti pembelajaran dengan model pembelajaran kooperatif tipe STAD dengan optimal. Hal ini dapat dilihat dari antusiasme siswa dalam mengikuti pembelajaran. Siswa berpartisipasi dengan baik dalam diskusi kelompok, presentasi, dan dalam mengerjakan tugas individu.

Berdasarkan pengamatan dan diskusi yang dilakukan antara peneliti dan guru pada siklus II, maka upaya perbaikan yang dilakukan secara umum dinyatakan berhasil. Oleh karena itu, pembahasan materi menyusun kertas kerja dan menyusun laporan keuangan diakhiri pada siklus II. 


\section{Respon Siswa}

Respon siswa terhadap model pembelajaran kooperatif tipe STAD dapat dilihat dari peningkatan motivasi dan hasil belajar siswa kelas XI IPS 1. Untuk mengetahui respon siswa, peneliti menggunakan angket peningkatan motivasi belajar siswa yang terdiri dari 7 indikator dengan jumlah keseluruhan pernyataan sebanyak 29 butir. Pada siklus I respon motivasi belajar siswa terhadap penerapan pembelajaran kooperatif tipe STAD diketahui sebanyak 12 siswa masih memiliki motivasi belajar sedang yaitu berada pada rentang $55 \% \leq X \leq 64 \%$, siswa lain yang berjumlah 20 siswa berada pada rentang skor $65 \% \leq X \leq 84 \%$ kategori tinggi. Apabila dilihat dari jumlah keseluruhan rata-rata kelas, respon motivasi belajar siswa sebesar $65 \%$ berada pada kategori tinggi dengan jumlah skor kelas sejumlah 2.429 dari skor maksimal 3.712.

Pada siklus II respon siswa terhadap motivasi belajar mengalami kenaikan, hanya satu siswa yang memiliki motivasi belajar sedang yaitu $61 \%$. Sejumlah 11 siswa telah mengalami peningkatan motivasi belajar jika dibandingkan dengan siklus I, pada siklus I mereka berada pada rentang skor sedang, namun pada siklus II mengalami peningkatan kategori ke skor tinggi sehingga terdapat 24 siswa telah berada pada rentang skor tinggi dan 7 siswa berada pada rentang skor sangat tinggi, hanya 1 siswa yang memiliki skor sedang. Rata-rata persentase kelas juga pada siklus II mengalami peningkatan jika dibandingkan dengan siklus I, peningkatan tersebut sebesar 13\%, dari rata-rata $65 \%$ menjadi $78 \%$ dan berada pada kategori tinggi. Jumlah skor kelas yang awalnya pada siklus I hanya 2.429, pada siklus II mengalami peningkatan pula sebesar 477 poin menjadi 2.906. Dapat disimpulkan bahwa siswa memiliki respon positif terhadap motivasi belajar akuntansi karena dari siklus I ke siklus II mengalami peningkatan yang cukup optimal, begitu pula dengan rata-rata persentase motivasi belajar kelas juga mengalami peningkatan.

Sedangkan penggunaan angket untuk mengetahui respon siswa terhadap pembelajaran kooperatif tipe STAD dijabarkan ke dalam 7 indikator dengan jumlah butir pernyataan sebanyak 23 butir. Respon siswa pada siklus I menunjukkan respon positif karena jika dilihat dari persentase rata-rata kelas sebesar $66 \%$ atau berada pada kategori skor tinggi, 11 siswa masih berada pada kategori skor sedang dan siswa lainnya yang berjumlah 21 siswa berada pada kategori skor tinggi. Peningkatan respon siswa dari siklus I ke siklus II juga mengalami peningkatan, pada siklus II hanya terdapat satu siswa yang rentang skornya berada pada kategori sedang yaitu $64 \%$, sebanyak 4 siswa telah mengalami peningkatan respon 
sehingga pada siklus II ini, 24 siswa berada pada rentang skor tinggi, siswa lain sebanyak 7 orang telah berada pada rentang skor sangat tinggi. Rata-rata kelas juga meningkat sebesar $13 \%$, dari siklus I yang hanya $66 \%$, pada siklus II naik menjadi $79 \%$ dan seluruh siswa kelas XI IPS 4 secara individu juga mengalami peningkatan skor. Oleh karena itu dapat disimpulkan bahwa siswa memberikan respon positif terhadap pelaksanaan pembelajaran kooperatif tipe STAD.

Secara keseluruhan hasil penelitian tindakan kelas ini terdiri dari dua siklus pembelajaran akuntansi dengan model pembelajaran kooperatif tipe STAD. Tujuan penelitian ini adalah untuk Meningkatkan Motivasi dan Hasil Belajar Akuntansi Siswa Kelas XI IPS 1 SMA Nurul Iman Palembang Tahun Ajaran 2015/2016 melalui Implementasi Model Pembelajaran Kooperatif Tipe STAD. Berdasarkan tujuan tersebut, maka jawaban dari hipotesis dan pertanyaan penelitian adalah sebagai berikut:

\section{Peningkatan Hasil Belajar Akuntansi Siswa melalui Implementasi Pembelajaran Kooperatif Tipe STAD . \\ Berdasarkan hasil analisis} penelitian ini menunjukkan bahwa terdapat peningkatan hasil belajar akuntansi siswa dengan implementasi model pembelajaran kooperatif tipe STAD. Hal ini ditunjukkan dengan peningkatan hasil belajar akuntansi siswa dari siklus I ke siklus II, hasil siklus I dan siklus II dapat dilihat pada tabel 3.

Tabel 3. Daftar Hasil Post-Test Nilai Siklus I dan Siklus II

\begin{tabular}{|c|c|c|}
\hline \multirow{2}{*}{ Rentang Nilai } & \multicolumn{2}{|c|}{ Frekuensi } \\
\cline { 2 - 3 } & Siklus I & $\begin{array}{c}\text { Siklus } \\
\text { II }\end{array}$ \\
\hline $93-100$ & 16 & 29 \\
\hline $85-92$ & 6 & 2 \\
\hline $77-84$ & 5 & 1 \\
\hline$\leq 76$ & 5 & 0 \\
\hline Jumlah siswa & 32 & 32 \\
\hline
\end{tabular}

Pada tabel 3, nampak bahwa hasil post-test pada siklus I sejumlah $15 \%$ atau 5 siswa dari 32 siswa masih belum mampu mencapai KKM, sebanyak 85\% siswa kelas XI IPS 4 telah mencapai KKM dengan nilai di atas 76. Pada siklus II, hasil post-test seluruh siswa mengalami peningkatan yang sangat baik yaitu $100 \%$ siswa telah mampu mencapai KKM dengan nilai lebih dari 76. Rata-rata kelas pada siklus I ke siklus II juga mengalami peningkatan sebesar 12,9 poin dari 85,9 menjadi 98,75 atau meningkat sebesar $15 \%$ dibanding siklus I. Siswa secara individual juga telah mengalami peningkatan nilai dari siklus I ke siklus II.

Indikator keberhasilan yang telah ditetapkan pada bab 3 yaitu apabila siswa secara individual mengalami peningkatan hasil belajar dari satu siklus ke siklus berikutnya 
dan sudah memenuhi Kriteria Ketuntasan Minimal (KKM) atau $\leq$ 76 juga telah terpenuhi. Berdasarkan hasil tersebut, maka hipotesis pertama pada penelitian ini adalah Implementasi Model Pembelajaran Kooperatif Tipe Student Teams Achievement Divisons (STAD) dapat Meningkatkan Hasil Belajar Akuntansi Siswa Kelas XI IPS 1 SMA Nurul Iman Palembang Tahun Ajaran 2015/2016.

Sejalan dengan hasil tersebut, maka penelitian ini juga telah sesuai dengan penelitian-penelitian relevan sebelumnya bahwa model pembelajaran kooperatif tipe STAD dapat meningkatkan hasil belajar siswa.

2. Peningkatan Motivasi Belajar Akuntansi Siswa melalui Implementasi Pembelajaran Kooperatif Tipe STAD

Terjadi peningkatan motivasi belajar siswa dari siklus I ke siklus II. Indikator keberhasilan menyebutkan apabila skor motivasi belajar siswa mengalami peningkatan dari satu siklus ke siklus berikutnya dan mencapai kategori tinggi yaitu $65 \%$ - $84 \%$ telah tercapai yaitu motivasi belajar siswa dari siklus I sebesar $67 \%$ mengalami kenaikan pada siklus II yaitu mencapai $86,5 \%$ pada rentang skor sangat tinggi. Hal ini menunjukkan telah terjadi peningkatan motivasi belajar siswa dari siklus I ke siklus II sebesar 19,5\%. Berdasarkan hasil tersebut, maka hipotesis kedua benar bahwa
Implementasi Model Pembelajaran Kooperatif Tipe Student Teams Achievement Divisons (STAD) dapat meningkatkan motivasi belajar Akuntansi siswa kelas XI IPS 1 SMA Nurul Iman Palembang Tahun Ajaran 2015/2016.

3. Respon Siswa

Respon siswa pada penelitian tindakan kelas ini hanya sebagai informasi tambahan bagaimana respon siswa terhadap implementasi pembelajaran kooperatif tipe STAD untuk meningkatkan motivasi dan hasil belajar siswa. Siswa memberikan respon positif terhadap pelaksanaan pembelajaran kooperatif tipe STAD.

Indikator keberhasilan respon siswa terhadap pelaksanaan pembelajaran kooperatif tipe STAD untuk meningkatkan motivasi belajar dapat dicapai dengan skor $65 \%$ pada siklus I, kemudian meningkat sebesar $13 \%$ pada siklus II yaitu mencapai $78 \%$. Indikator keberhasilan respon siswa terhadap pelaksanaan pembelajaran kooperatif tipe STAD untuk meningkatkan hasil belajar Akuntansi juga telah dicapai dengan skor tinggi yaitu $79 \%$ pada siklus II yang telah mengalami peningkatan sebesar 13\% dibandingkan siklus I yaitu 66\%. Berdasarkan hasil penelitian tersebut, maka Implementasi Model Pembelajaran Kooperatif Tipe Student Teams Achievement Divisons (STAD) untuk Meningkatkan Motivasi dan Hasil Belajar Siswa Kelas XI IPS 1 SMA 
Nurul Iman Palembang Tahun Ajaran 2015/2016 mendapatkan respon positif dari siswa.

\section{Kesimpulan}

1. Pembelajaran kooperatif tipe STAD dapat meningkatkan hasil belajar siswa. Pada siklus I sebanyak 5 siswa yang tidak mencapai KKM, namun pada siklus II telah terjadi peningkatan yaitu $100 \%$ siswa telah mencapai KKM dengan nilai rata-rata kelas meningkat sebesar 12,9 poin dari 85,9 pada siklus I, menjadi 98,75 pada siklus II.

2. Pembelajaran kooperatif tipe STAD dapat meningkatkan motivasi belajar siswa. Pembelajaran kooperatif tipe STAD berperan dalam meningkatkan motivasi belajar siswa. Hal ini ditunjukkan peningkatan jumlah skor pada siklus I jumlah skor rata-rata siklus I adalah 497 dan persentase motivasi belajar siswa sebesar $67 \%$. Pada siklus II dihasilkan skor rata-rata sebesar 643,5, sehingga persentase motivasi belajar sebesar 86,5\%. Berdasarkan kategori skor, rentang skor $86,5 \%$ tergolong skor kategori sangat tinggi. Apabila dibandingkan, motivasi belajar siswa dari siklus I ke siklus II mengalami kenaikan sebesar 19,5\%. Siswa memberikan respon positif terhadap pelaksanaan pembelajaran kooperatif tipe STAD.

3. Respon siswa terhadap pembelajaran kooperatif tipe STAD untuk meningkatkan motivasi dan hasil belajar akuntansi siswa menunjukkan respon positif. Hal ini nampak melalui respon motivasi dan hasil belajar siswa yang mengalami peningkatan dari siklus I ke siklus II masingmasing mengalami kenaikan yang sama yaitu sebesar 13\%. Data tersebut juga didukung melalui angket respon siswa terhadap pembelajaran kooperatif tipe STAD yang mendapatkan respon positif dari siswa.

\section{DAFTAR PUSTAKA}

Al Haryono Jusup. (2001). Dasardasar Akuntansi Jilid 1. Yogyakarta: Aditya Media.

Asep Jihad dan Abdul Haris. (2008). Evaluasi Pembelajaran. Yogyakarta: Multi Pressindo.

Baharuddin dan Esa Nur Wahyuni. (2009). TEORI BELAJAR DAN PEMBELAJARAN. Jogjakarta: Ar-Ruzz Media.

Departemen Pendidikan dan Kebudayaan. (1993). Evaluasi dan penilaian. Jakarta: Proyek Peningkatan Mutu Guru Dirjen DIKNASMEN.

Dimyati dan Mudjiono. (2003). Belajar dan Pembelajaran. Jakarta: Depdikbud.

Dyah Suryani. (2011). Implementasi Model Cooperative Learning 
Tipe Student Team Achievement Division (STAD) untuk Meningkatkan Motivasi Belajar Siklus Akuntansi Perusahaan Jasa Siswa Kelas XI IPS SMA Angkasa Adisutjipto Yogyakarta Tahun Ajaran 2010/2011. Skripsi. Yogyakarta: FE UNY.

Fathurrohman, Pupus dan Sutikno, Sobry. (2007). Strategi Belajar Mengajar. Bandung: PT Refika Aditama.

Fudyartanto, Ki RBS. (2002). Psikologi Pendidikan dengan Pendekatan Baru. Yogyakarta: Global Putaka Ilmu.

Hasbullah. (2005). Dasar-dasar Ilmu Pendidikan. Jakarta: PT Raja Grafindo Persada.

Icha Dian Saraswati. (2010). Penerapan Model Pembelajaran Kooperatif Tipe STAD (Student Team Achievement Division) untuk Meningkatkan Motivasi dan Hasil Belajar Siswa Pada Mata Pelajaran Manajemen Perkantoran (Studi Pada Siswa Kelas X Program Keahlian Administrasi Perkantoran di SMK Muhammadiyah 2 Malang). Skripsi. Malang: FIS UNM.

Isjoni dan Arif Ismail. (2008). Model-Model Pembelajaran Mutakhir Perpaduan Indonesia-Malaysia.

Yogyakarta: Pustaka Pelajar.

Iskandar. (2009). Penelitian Tindakan Kelas. Jakarta: Gaung Persada (GP) Press.

Mohamad Nur. (2005). Pembelajaran Kooperatif. Surabaya: Pusat Sains dan Matematika Sekolah UNESA.
Muhibbin Syah. (2002). Psikologi Belajar. Jakarta: PT. Raja Grafindo Persada.

Mulyono Abdurrahman. (2003). Pendidikan Bagi Anak Berkesulitan Belajar. Jakarta: Rineka Cipta.

Oemar Hamalik. (2003). Proses Belajar Mengajar. Jakarta: Bumi Aksara.

Richard I. Arends. (2008). Learning To Teach Belajar Untuk Mengajar. Yogyakarta: Penerbit Pustaka Pelajar.

Sardiman, A.M. (2007). Interaksi dan Motivasi Belajar Mengajar. Jakarta: PT Raja Grafindo Persada.

Slameto. (2003). Belajar dan FaktorFaktor yang Mempengaruhinya. Jakarta:Rineka Cipta

Sudirman , dkk. (1992). Ilmu Pendidikan. Bandung: Remaja Rosda Karya.

Sugihartono; dkk. (2007). Psikologi Pendidikan. Yogyakarta: UNY Press.

Sugiyono. (2010). Metode Penelitian Pendidikan Pendekatan Kuantitatif,Kualitatif, dan $R$ \& $D$. Bandung: Alfabeta.

Sukarmin. (2002). Pembelajaran Kooperatif. UNESA: Surabaya.

Sumadi Suryabrata. (1995). Psikologi Pendidikan. Jakarta: C.V. Rajawali.

Trianto. (2009). Mendesain Model Pembelajaran InovatifProgresif: Konsep,Landasan, dan Implementasinya pada Kurikulum Tingkat Satuan Pendidikan (KTSP). Jakarta: Prenada Media Group.

Undang-Undang Republik Indonesia No. 20. Tahun 2003 Tentang 
Sistem Pendidikan Nasional. Jakarta: Sinar Grafika.

Wiriatmadja Rochiati. (2009). Metode Penelitian Tindakan Kelas. Bandung: Rosdakarya.

Yatim Riyanto. (2008). Paradigma Baru Pembelajaran (Sebagai Referensi bagi Guru dalam Implementasi Pembelajaran yang Efektif dan Berkualitas). Surabaya: Prenada Media.

(2010). Mendesain Model Pembelajaran InovatifProgresif: Konsep,Landasan, dan Implementasinya pada Kurikulum Tingkat Satuan Pembelajaran. Jakarta: Kencana.

Zainal Aqib. (2009). Penelitian Tindakan Kelas. Bandung: Krama Widya.

Zainal Arifin. (1991). Evaluasi Instruksional: Prinsip-TeknikProsedur. Bandung: Remaja Rosdakarya.

Zaki Baridwan. (2000). Intermediate Accounting. Yogyakarta: BPFE. 